\section{Exploring social media usage as a communication channel among independent food retailer SMEs in South Africa}

\author{
Análisis exploratorio del uso de las redes sociales como canal de \\ comunicación en las PYMES independientes del comercio minorista de \\ alimentación en Sudáfrica
}

José dos Santos ${ }^{\mathrm{a}} \sim(\mathbb{0})$, Rodney Duffett ${ }^{\mathrm{b}, *} \nabla$ (1)

a, b) Cape Peninsula University of Technology, Marketing Department. Cape Town (South Africa)

* Primary Contact:duffetr@cput.ac.za (Rodney Duffett)

\begin{abstract}
Social media has facilitated interaction between businesses and consumers, and consequently, has seen rapid growth as a communication channel by a number of smaller retailers in South Africa. Hence, the primary research objective of this study is to explore social media usage as a marketing communication strategy by independent food retailer small to medium enterprises (SMEs). The study used a qualitative data collection strategy and in-depth interviews were conducted among eleven independent food retailer SMEs in South Africa. The study revealed that the level of social media activity by the respondent retailers was influenced by enabling factors such as cost effectiveness, accessibility, reach and relationship building, whereas perceived risk and resources such as time, knowledge and human resources were inhibiting factors. The research contributes to the available literature exploring social media usage as customer contact points for promotional purposes, as well as provides insight for further studies on the use of social media conduits by independent food retailer SMEs or similar businesses in a developing country.
\end{abstract}

Keywords: independent food retailer; SMEs; small businesses; social media; communication strategy; South Africa; developing country JEL Classification: M30; M37; L81; O33

\begin{abstract}
Resumen
Las redes sociales han facilitado la interacción entre las empresas y los consumidores y, en consecuencia, han experimentado un rápido crecimiento como canal de comunicación por parte de algunos negocios minoristas de Sudáfrica. Por ello, el objetivo principal de este estudio es explorar el uso de las redes sociales como estrategia de comunicación de marketing por parte de las pequeñas y medianas empresas (PYMES) minoristas de alimentación independientes. El estudio utilizó una estrategia cualitativa de recogida de datos y se realizaron entrevistas en profundidad a once PYMES minoristas de alimentación independientes de Sudáfrica. El estudio reveló que el nivel de actividad en los medios sociales por parte de los minoristas encuestados estaba influenciado por factores favorables como la rentabilidad, la accesibilidad, el alcance y la creación de relaciones, mientras que el riesgo percibido y los recursos como el tiempo, los conocimientos y los recursos humanos eran factores inhibidores. Esta investigación contribuye a la literatura disponible que explora el uso de los medios sociales como puntos de contacto con los clientes con fines promocionales, así como proporcionar una visión para futuros estudios sobre el uso de los conductos de los medios sociales por parte de las PYME minoristas de alimentos independientes o negocios similares en un país en desarrollo.
\end{abstract}

Palabras clave: comercio minorista de alimentación; PYMEs; pequeña empresa; social media; estrategia de comunicación; Sudáfrica; países en desarrollo

Clasificación JEL: M30; M37; L81; O33 


\section{Introduction}

Independent food retailer SMEs face ongoing challenges to protect the viability of their stores as retail groups and franchise operations expand their footprint into areas previously dominated by the independent retailers (Makhitha, 2016). The introduction of smaller format stores by the retail chain groups, which include convenience and forecourt stores that have extended trading hours, as well as a range of value-added services such as cellular products, third party payments and financial services represent some of the changes that have taken place in the South African food retail industry over the last few years, which have impacted on the competitiveness of the independent retailer (Das Nair \& Dube, 2015; Malgas et al., 2018). The Department of Trade and Industry defines independent retailers as part of the medium, small and micro enterprises that employ fewer than 250 staff and have an annual turnover below R80 million per year (DSBD, 2019). In this instance, the respondent retailers achieve between R7 million and R15 million turnover per year with an average staff compliment of 20. Independent retailers usually trade in a specific area and serve the community around them. They do not belong to a larger chain or group. Independent retailers are usually managed by the owner and, generally, have less financial capacity or the ability to conduct promotional programs (Makhitha, 2017; Schmidt et al., 2017; Salam et al., 2021).

The evolution of social media has made this information and communications technology (ICT) medium an important element of the communications process with communities, companies and consumers because of its interactive nature, which allow users to create content and share it with others. It highlights the transition from merely collecting information and consuming it to creating and adding to the information available on platforms that allow it (He et al., 2017; Kemp, 2018, Duffett, 2020). Social media is technically easy to use, cost effective and accessible to a large variety of customers, which presents an opportunity to small and medium companies who might not have financial and technical resources for traditional marketing programs (Gujral et al., 2016; He et al., 2017; Bae \& Zamrudi, 2018; Duffett, 2020, Ntshingila, 2020; Qalati et al., 2021; Qalati et al., 2020; Saleh, 2021). Major South African retailer groups have multifaceted marketing strategies, which include a presence in the different social network sites and use social media as a communication channel (Shoprite Holdings, 2020; Pick n Pay, 2020; Woolworths, 2020). However, little is known whether independent food retailer SMEs use social media to promote their businesses in South Africa, so this current study seeks to expand on this knowledge gap.

There is a growing body of literature on social media and communication strategies in mainly developed nations. Ainin et al. (2015); Bocconcelli et al. (2017); Bae and Zamrudi (2018); Appel et al. (2020); Chatterjee and Kumar Kar (2020); Fan et al. (2021); Gabbianelli and Pencarelli (2021); and Siti-Nabiha et al. (2021) have investigated factors influencing the adoption of this ICT channel, whereas others have conducted enquiries into the extent and mode of social media implementation (Harris \& Rae, 2009; McCann \& Barlow, 2015; Taiminen \& Karjaluoto, 2015; Barnard et al., 2017; Torres de Oliveira et al., 2020; Olanrewaju et al., 2020; Olsson \& Bernhard, 2020). From an African developing country perspective, researchers such as BadenhorstWeiss and Cilliers (2019); Das Nair and Dube (2015); Makhitha (2016); Amoah and Jibril (2021); and Lányi et al. (2021) investigated factors affecting competitiveness and the impact of marketing strategies on profitability. Similar research to the current study was conducted by Rootman (2016) and Jordan (2018), where the former assessed the impact social media tools had on brand image and buying behavior in the South African retail industry from a consumer perspective, and the latter investigated the usage of social media marketing strategies by small retailers in the United States (US). Therefore, given the importance ascribed to SME social media marketing, it is important to understand how small retailers are adapting to the digitization of communication in developing countries, which is also identified by Kongolo (2010); Makhitha (2016); and Goko (2017) as gaps in knowledge that warrant further inquiry. Hence, this exploratory study seeks to understand the extent that independent retailers have adopted social media as a marketing communications strategy in an African developing country; the factors that influence its adoption; and to identify elements that impede its application as a business resource.

A number of new studies identify other research gaps. Several inquiries assert that additional research is necessary to investigate the use of social media marketing by SMEs in other countries (Lepkowska-White et al., 2019; Gabbianelli \& Pencarelli, 2021; Kwon et al., 2021), especially in developing countries (Alzougool, 2019; Qalati et al., 2021; Salam et al., 2021). Rajahonka and Villman (2019); Olsson and Bernhard (2020); and Siti-Nabiha et al. (2021) stress that further research is required to explore how SMEs use and implement social media, as well as investigate the associated benefits and drawbacks. Alzougool (2019) emphasizes that additional research is necessary to consider social media usage by SMEs from a business-to-consumer context. Lepkowska-White et al. (2019) mandate further study is needed to assess how social media usage could improve SME marketing. Kwon et al. (2021) assert that social media is an important marketing and communications tool for SMEs, but there is a lack of inquiry that examines the factors that influence social media usage intentions.

The underlying theoretical model applicable to this study is the Technology Acceptance Model (TAM), which theorizes that perceived usefulness (PU) and perceived ease of use (PEOU) have a positive influence on attitudes and behavioral intentions toward new technology usage (Davis, 1989; Davis et al., 1989). Though, 
this current qualitative study will not endeavor to empirically test the associations between the aforementioned TAM variables, since several other recent SME marketing-related inquiries have already found positive associations between PU and PEOU, and social media behavioral/usage intentions (Chatterjee \& Kumar Kar, 2020; Sutomo et al., 2020; Tumsifu and Gekombe (2020); Kwon et al., 2021; Salam et al., 2021). A number of external variables were found to have an influence on technology adoption/usage in revised versions of the TAM (Venkatesh \& Davis, 2000; Venkatesh \& Bala, 2008) and the abovementioned SME social media marketing-related studies across various sectors and countries (Chatterjee \& Kumar Kar, 2020; Sutomo et al., 2020; Tumsifu \& Gekombe, 2020; Kwon et al., 2021; Salam et al., 2021). So, this study seeks to make an original contribution to literature by examining the external factors that promote or impede the use of social media as a communication channel from an African independent food retailer SME perspective.

Hence, to address the aforementioned gaps in research and investigate the external factors, the main research objective of this study is to explore social media usage as a marketing communication strategy by independent food retailer SMEs. The study seeks to establish the enabling factors that facilitate the promotion of such stores, and clarifies the inhibiting obstacles that prevent social media usage in South Africa.

\section{Literature review and conceptual framework}

\subsection{South African Retail Market Structure}

The South African food retail landscape is dominated by several groups (Spar, OK Franchise Division, Pick $\mathrm{n}$ Pay Express and Cambridge), which collectively account for an estimated half of the R1 trillion in sales, as reported by their respective integrated financial reports and retail trade sales (Pick n Pay, 2020; Shoprite Holdings, 2020; Massmart, 2020; OK Foods, 2021; Spar, 2021; Statista, 2021). Sales distribution through retail channels indicated that $64 \%$ of food was sold through hypermarkets and supermarkets, $28.9 \%$ by independent retailers and specialty stores, whilst convenience stores accounted for $4.5 \%$, and $2.7 \%$ through other channels (MarketLine, 2015). The saturated nature of the South African market and the need to show continuous growth has resulted in the major retail groups setting up operations throughout Africa. Retailers have also extended their store mix and developed multichannel strategies, which include online shopping platforms as a way of remaining competitive (Geller \& Ntloedibe, 2019; Winchester, 2017; Salam et al., 2021).

Generally, independent retailers are single store operations and tend to be smaller with lower sales levels. This facilitates direct contact between the owner and customer, which promotes relationship building. Small retailers can react quickly to changing customer needs (Srichookiat \& Jindabot, 2017; Kelso, 2018). The strategic management decisions of small businesses are to a large degree dictated by the market. This is because these small entrepreneurs are unable to influence the market in which they operate and are generally price takers due to challenges such as lack of sales volume, restricted resources and limited customer base (Curran \& Blackburn, 2001). This reality is reflected by Ligthelm (2008) who noted that small businesses had experienced a $47 \%$ decline in sales as a result of the introduction of shopping malls in Soweto (a large urban township situated in Johannesburg, South Africa). Small businesses can be competitive by being able to react quickly to changing customer needs and providing superior customer service, as well as by constant innovation (Badenhorst-Weiss \& Cilliers, 2019; Grimmer et al., 2017; Boonmalert et al., 2021; Kwon et al., 2021).

Retailers can also be divided into two major purchase modes that might be affected through physical stores or online retail, although the difference between the two is blurring as omni-channel shopping becomes the norm (von Briel, 2018). Different types of retailers survive because they meet customer needs better than their competitors (Levy \& Weitz, 2012). Given this situation, traditional retailers are adapting to the new rules of retail brought about by the technology-enabled disruption that has empowered customers to shop at their convenience via the channel of their choice. Retailers not adapting to this evolving competitive environment will close their doors like Sears in the US and Stuttafords in South Africa (Kumwenda-Mtambo \& Strydom, 2017; Thomas, 2018). Advanced point of sale systems, accessibility to the internet, and the growth of social media have changed the way the retailer and customer interact. New retail models have developed because of technologies. e-Commerce has become an additional distribution network for traditional retailers, whereas once exclusively online retailers have introduced physical stores (Grewal et al., 2017; Wells, 2018).

\subsection{Social Media as a Communication Channel}

The available literature investigating the use of social media by SMEs as a strategy to market their businesses reveal that networking, establishing customer relationships, business growth and being competitive were motivating usage factors (Rootman, 2016; Crammond et al., 2018; Ndiege, 2019; Chatterjee \& Kumar Kar, 2020; Lányi et al., 2021). Several inquiries emphasized that restricted resources, technical capabilities, and adverse usefulness sentiments were impediments to social media usage (Michaelidou et al., 2011; Jagongo \& Kinyua, 2013; Ainin et al., 2015; Braojos-Gomez et al., 2015; Grimmer et al., 2017; Tuten \& Perotti, 2019). Further studies found that social media had a positive effect on the profitability and/or performance of businesses, and the ICT channel was seen as technically accessible and cost effective (Bocconcelli et al., 2017; 
Fan et al., 2021; Lányi et al., 2021; Qalati et al., 2020; Qalati et al., 2021). The most dominant social medium appealing to customers in the retail sector was Facebook (Odoom et al., 2017). However, a majority of the abovementioned studies were conducted in developed countries, so further research is required from a developing country context.

Research into small and medium enterprises have revealed varying motivations for using social media platforms as a channel through which they can promote themselves. Most agreed that this online ICT medium presented growth potential that could be extracted from the promotional and networking opportunities offered by connecting directly with customers through this cost-effective communication channel (Odoom et al., 2017; Gbadeyan \& Mensah, 2016; Ramanathan et al., 2017; Bae \& Zamrudi, 2018; Basri \& Siam, 2019; Salam et al., 2021). He et al. (2014) investigated social media platform usage as a means to enhance community relationships and social responsibility by 32 small pizzerias, whilst Dahnil et al. (2014) looked at causes that affect the adoption of social media marketing by small to medium enterprises (SMEs). He et al. (2017) conducted a further case study survey which investigated the adoption of social media for business purposes by 27 small enterprises in a mid-sized US city. Michaelidou et al., 2011 revealed in a similar study that business-to-business SMEs in the United Kingdom (UK) adopted social media with brand building as the objective. Further studies have investigated the impact social media usage on small businesses that have adopted it as a marketing channel (Braojos-Gomez et al., 2015; Gujral et al., 2016; Ahmad et al., 2018; Crammond et al., 2018; Chatterjee \& Kumar Kar, 2020; Ntshingila, 2020). Though, most of these inquiries emanated from developed nations and did not consider the food retail sector, thus additional inquiry is needed from a developing nation perspective and the food retail sector.

Research tracking social media usage as a marketing channel, found that in some instances, consumers became more active and in particular on Facebook, which has been accessible because of familiarity and popularity as a social network platform (Kemp, 2018). Social media leads to customer interaction, which can be utilities to establish relationships with them, as well as increase brand recognition and decrease marketing expenditure (Rootman, 2016; Barnard et al., 2017; Lepkowska-White et al., 2019). This view is supported to a large degree by the results of the South African Social Media Landscape survey, which indicated that 91\% of the 116 participating brands used Facebook, 88\% used Twitter and 66\% YouTube (Goldstuck \& Du Plessis, 2016). This notion is confirmed by Bae and Zamrudi (2018), who investigated the challenges and effect of social media customer engagement by retailers in Indonesia. The inquiry established that customers were kept informed promotional content, engagement and brand visibility via social media. However, brands are still unclear as to their social media strategy effectiveness. Possible reasons could be attributed to imprecise promotion measurement factors, the lack of management support, and poor departmental coordination. Other factors that might influence the adoption of social media as a marketing medium are the age and the literacy in online communication by the business owner. A trend towards investing in people within a company rather than outsourcing to carry out the social media strategy function was noted by several studies (He et al., 2017; Bae \& Zamrudi, 2018; Olsson \& Bernhard, 2020).

\subsection{Technology Acceptance Model and Conceptual Framework}

The TAM is one of the most broadly used theoretical frameworks to examine and understand the propensity for organizations to accept and use technology in finding business solutions. The original model postulates that PU and PEOU have a favorable influence on attitudes and behavioral intentions in terms of the use and adoption of various technology (Davis, 1989). Subsequent developments of the TAM show that a number of external variables also influence attitudes and behavioral intentions regarding the use and acceptance of digital technology, but the principle notion that the usefulness of new technology positively affect its adoption remains unaltered (Venkatesh \& Davis, 2000; Venkatesh \& Bala, 2008; Dwivedi et al., 2011). As mentioned in the introduction, this current investigation does not focus on the influence of PU and PEOU on social media behavioral/usage intentions as these associations were recently examined by other SME marketing-related research (Chatterjee \& Kumar Kar, 2020; Sutomo et al., 2020; Kwon et al., 2021; Salam et al., 2021). Several inquiries (mostly systematic reviews) identify that the TAM is the most widely used model to investigate new technology (mobile and social media), and/or also identify numerous external variables that were employed to consider the impact on behavioral/usage intentions, which is the focus of this current study (except that these studies predominantly focus on the consumers and not SMEs' technology usage) (Wirtz \& Göttel, 2016; Chhonker et al., 2017; Liu et al., 2019; Al-Qaysi et al., 2020; Al-Qaysi et al., 2020; Ngubelanga \& Duffett, 2021).

Some SME social media marketing-related studies used the TAM to identify a number of external variables, which had positive or negative effect on social media behavioral/usage intentions in several industries and different nations. Chatterjee and Kumar Kar (2020) identified social media marketing adoption SME factors and their impact on the businesses in India. The inquiry revealed that social media marketing adoption had a positive impact on the business (via increased customers, sales, enquires, and feedback, as well as improved customer relationships). The converse was applicable in terms of the costs, which resulted in unfavorable sentiment regarding social media usage. Sutomo et al. (2020) established that trust, facilitating conditions, and the quality of information influenced social commerce (sales via social media) by SMEs in Malaysia. Kwon 
et al. (2021) found that SMEs' perceived barriers (such as the lack of knowledge, skills and expertise, as well as high cost) yielded a negative impact on SMEs social media usage intentions in the US. Salam et al. (2021) found that a number of Pakistani SMEs did not have the knowledge or skills to employ social media marketing during the COVID-19 crisis. However, the study also revealed that others realized their potential and implemented social media marketing strategies, which resulted in improved sales, lower costs than traditional media, and improved customer relationships.

A number of other studies (in addition to those already discussed in aforementioned text) also considered external factors (in the form of enabling factors and/or drivers) of social media usage and/or digitalisation of SMEs across a number of different sector and countries (refer to Table 1). Several other studies identified the potential inhibiting factors of social media usage and/or digitalisation of SMEs, which may have diminished behavioural intentions (refer to Table 1).

Table 1. External Factors Influencing the Use of SME Social Media Marketing Authors

Alzougool (2019)

Basri and Siam (2019)

Lepkowska-White et al. (2019)

Ndiege (2019)

Itliong (2020)

Amoah and Jibril (2021)

Boonmalert et al. (2021)

Gabbianelli and Pencarelli (2021)

Lányi et al. (2021)

Matarazzo et al. (2021)

Olsson and Bernhard (2020)

Qalati et al. (2020)

Qalati et al. (2021)

Siti-Nabiha et al. (2021)

Steel (2021)

Source: Own elaboration

Table 1 outlines the enabling and inhibiting external factors of social media usage and/or digitalisation among SMEs, and used in conjunction with prior discourse, serves as the basis for conceptual framework. This study endeavours to examine which external factors (and possibly identify unique factors) are relevant to social media usage as a marketing communication strategy by independent food retailer SMEs in South Africa. Refer to Figure 1 for an overview of the proposed conceptual framework (it is important to note that not all of the enabling and inhibiting factors outlined in the conceptual framework will be viewed as important by the independent food retailer SMEs in South Africa).

Social media platforms were mainly used for sales, marketing, communication and information, whereas security and fake identities were risks associated with the use of social media by SMEs in Kuwait

Social media served as a marketing platform that increased sales, reduced marketing costs, provided an innovative edge, increase profitability, and served a direct customer relation communication portal for Arabian SMEs.

American SME restaurants used social media for promotional activities in order to increase awareness, customer numbers, relationships and sales; stimulate customer engagement; and gather information on customers and competitors, which saved on market research and marketing costs. Several SMEs indicated that they did not have the time, finance or expertise (know-how) to implement social media strategies effectively.

Social media technologies generated benefits such as lead generation, new customers, increased sales and improved customer interaction in Kenyan SMEs. The associated challenges were time restraints, the conversion of data into useful information, and the management of reputational threats that emerged from customer feedback.

SMEs could derive improved customer relations and social commerce (sales) from the use of social media among restaurants in the US.

Social media usage as a promotional advertising tool positive influenced: market share and sales, customer relations, business motivation and financial performance among financial SMEs in Ghana

Digital marketing resulted in a positive effect on SMEs' performance (sales and customer retention) in Thailand.

A majority of SMEs used social media and websites for marketing and communication tactics, especially for the purposes of customer relationship maintenance in Italy.

Social media conduits and websites usage were found to favourably influence SMEs' competitiveness in Bosnia and Herzegovina, Colombia, Costa Rica, Czech Republic, France, Hungary, Mexico and Spain.

Social media use resulted in several benefits for SMEs in Italy, viz.: customer engagement, new communication channel, new supply channel, entertainment, social presence, customer relations, direct sales, and overall value to the business model.

The challenges to SME social media usage were identified as limited resources, maintenance of social media platforms, and the need to continually learn new digital skills in the Swedish tourist sector.

Social media usage was found to improve the performance of SMEs in Pakistan. The use of social media by Pakistani SMEs enhanced their performance.

SMEs used social media to understand competitors; to establish and maintain relationships with customers; and social media data was used for promotion, pricing and strategy development in the Malaysian hospitality industry.

Social media usage resulted in several benefits for SMEs in Sudan, namely a sales and marketing channel; reach potential customers; and served as a supply channel. 
Figure 1. Proposed Conceptual Framework

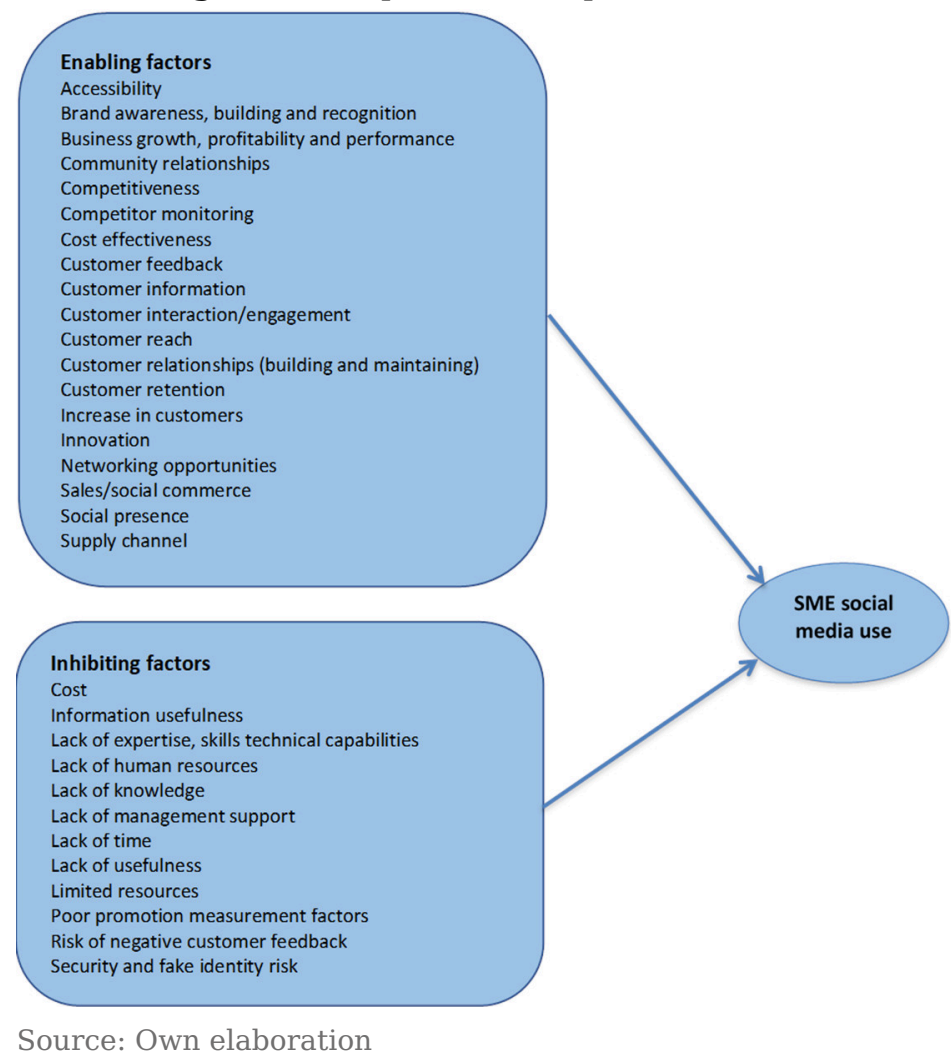

\section{Methods}

A qualitative research design was the chosen methodology based on its ability to answer the research questions suitably (Njie \& Asimiran, 2014). The exploratory research strategy undertaken in this study endeavored to gain further information regarding the South African food retail industry and its operational makeup; specifically in terms of social media usage as a marketing communication channel by independent food retailer SMEs. In the current study, a non-probability judgmental sample design facilitated an understanding of the experiences of the chosen group or individuals (Sarstedt \& Mooi, 2014; Hair et al., 2017). Creswell (2013) suggests three types of case studies, namely: single case study, the collective and multiple case studies. A case can be a group, individual, a community, an instance, population subgroup, a town or a city. To be called a case study, the total study population must be treated as one entity. The case becomes the focus of an in-depth exploration of all the idiosyncratic complex aspects that are being considered in a bounded system and not the whole population of cases (Zikmund \& Babin, 2013). Multiple case study research is an exploratory approach in which the investigator explores a bounded system (case) or multiple cases over time, through a detailed, in-depth data collection involving multiple sources of information. The current research has adopted a multiple case study approach and a total of eleven cases (independent retailers) situated in the Cape Town region were examined by this study. Similar studies were carried out by He et al. (2017) as a way of revealing the multiple facets that influenced decisions regarding the adoption of social media by 27 small businesses in a mid-size US city. The in-depth interviews in this study indicated that the ease of use, adopter's age and educational level, conversancy with this medium and peer influence played a role in their decision. Ndiege (2019) conducted a study in Kenya in which the use of social media as a positioning strategy was investigated. In this instance, the sample size was determined by the lack of the emergence of new data during the interviews. This method is also referred to as the saturation point (Creswell, 2013). The respondents to that study were purposefully selected as they were considered as having knowledge regarding the business social media strategy.

The targeted respondents of the current study were independent food retailer SMEs located in the Cape Town region, which in most instances were run by the owners. The owners were thought to be the most suitable as these information-rich individuals would provide good insight in responding to the research questions (Tongco, 2007). The communication with the respondents started by means of an introductory email and invitation to participate in the survey. A letter of acceptance to participate in the survey was requested from the respondents, which was followed up with telephonic communication to secure an appointment with the independent retailer to conduct the in-depth interview at their business in order to minimize inconvenience to the respondents. As this was a purposive sample, the communication was conducted by the researcher in order to minimize refusals. The purpose and objectives of the research was shared with the potential respondents with regard to the benefits that might result as a consequence of their participation. The in-depth interview was the primary data collection technique, which entailed a detailed interview to explore the 
perspective of independent food retailer SMEs with regard to the barriers that inhibit is use as well as the factors that enable the adoption and social media platforms use as part of their marketing communication strategy. This was achieved by using a semi-structured interview, which varied in duration from about thirty minutes to about an hour, which was sufficient to cover all of the necessary questions and discussion, and provided for prompts to explore themes that emerged during the interview (Boyce \& Neale, 2006). There was no set cap on the number of respondents to provide the required information to answer the research questions, but the sample size was regarded as sufficient or attained saturation point when the interviews added no new data and the number of respondents ended on eleven (Seidler, 1974; Marshall, 1996). This type of sample, however, cannot be generalized to a larger group as the experiences are unique to the respondents of the study (Wilson, 2006; Creswell, 2013; Wiid \& Diggines, 2013). The table below gives a brief description of the type of retailer that participated in the study.

Table 2. Description of Study Respondents

\begin{tabular}{|c|c|c|c|c|}
\hline $\begin{array}{l}\text { Business } \\
\text { Name }\end{array}$ & Area & Store Type & Respondent & $\begin{array}{c}\text { Time in Current } \\
\text { Business }\end{array}$ \\
\hline 1 & Goodwood & Community convenience store & Owner & 20 years + \\
\hline 2 & Durbanville & Community convenience store & Owner & 10 years + \\
\hline 3 & Bellville & Community convenience store & Manager & 1 year \\
\hline 4 & Cape Town & Deli-type retailer & Owners & 10 years + \\
\hline 5 & Cape Town & Specialist fish retailer & Owner & 10 years + \\
\hline 6 & Parow & Community convenience store & Owner & 2 years \\
\hline 7 & Kenilworth & Deli-type retailer & Owner & 10 years + \\
\hline 8 & Rugby & Community convenience store & Manager & 10 years + \\
\hline 9 & Belhar & Community convenience store & Owner & 15 years + \\
\hline 10 & Durbanville & Community convenience store & Owner & 15 years + \\
\hline 11 & Noordhoek & Community convenience store & Manager & 20 years + \\
\hline
\end{tabular}

Taylor and Gibbs (2010) describe qualitative data analysis as a set of activities that transform the mass of raw collected data into a set of themes from which an interpretation of situations or people under investigation is derived. The analysis of the collected data follows specific stages that include familiarizing oneself with the material by reading the transcripts thoroughly and gaining a comprehension of the information at hand. A list of topics coming from the interviews is compiled and similar topics are clustered together into coded themes to facilitate quick retrieval. The reduced data is analyzed and reconstructed into an interpreted representation of the responses in order to answer the research questions of the study. The current study followed this process, which included the transcription of the interview recordings. Additional information in the form of screen grabs of activity on the respondent social network platforms was collected as a way of enhancing the quality of the collected data (Taylor \& Gibbs, 2010; Creswell, 2013). ATLAS.ti (version 8) software was used to transcribe and code the interviews. The eleven input documents created a number of code groups which were further divided into family groups to facilitate identification and reference back to the research questions and objectives.

\section{Results}

The results revealed that there were several main supporting and enabling external factors, as well as considerations that impeded adoption and social media use as a communication conduct. Several respondents referred to the PU and PEOU of social media, which corroborated that these factors had a positive influence on social media use according to the TAM.

“No problems in maintaining the Facebook page." [R9/3311:3356] ${ }^{1}$

"I know it (social media) is useful...." [R10/1149:1241]

However, as mentioned in prior discourse, the aim of the study was to examine which external (enabling and inhibiting) factors influenced social media usage as a marketing communication channel.

\subsection{Enabling Factors}

Figure 2 illustrates the enabling factors (based on the TAM theory) that promote social media usage as a communication conduit by independent food retailer SMEs in South Africa. 
Figure 2. Factors Enabling Social Media Usage

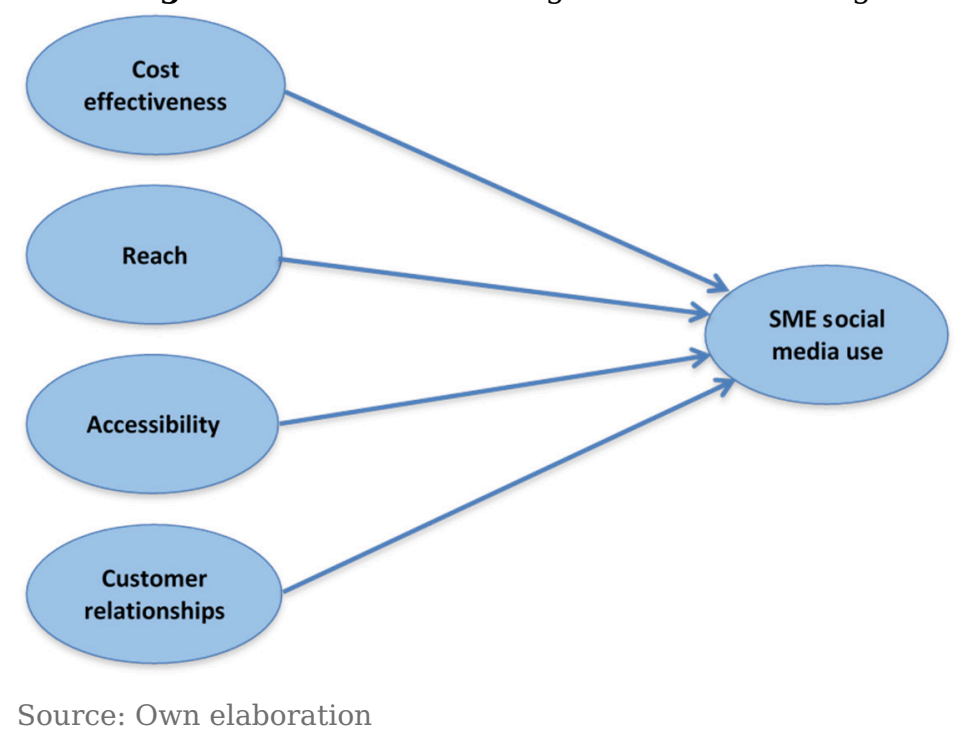

\subsubsection{Cost Effectiveness}

The general sentiment of the respondents was that the social network platforms such as Twitter, Instagram, Pinterest, WhatsApp and Facebook all offered a cost effective channel to engage with customers and promote their businesses. Several respondents indicated that they did not have a budget and relied on word of mouth generated from their posts, whereas other respondents used their Facebook pages as a means to promote instore specials without incurring cost. Available literature suggests that small businesses lack resources, including financial capacity to promote themselves (Dlodlo \& Dhurup, 2010; Ainin et al., 2015; He et al., 2017; Crammond et al., 2018; Ndiege, 2019; Chatterjee \& Kumar Kar, 2020; Ntshingila, 2020; Saleh, 2021), and therefore seek more cost-effective methods.

"We advertise in the community newspaper but it became too pricy and Facebook was picking up hugely with everyone using Facebook and everyone has Facebook on their phones ...." [R2/722:1037]

The results of the current study support this perspective since several respondents had been using traditional media, such as print, but had switched to social network platforms as it was more cost effective. This finding is in agreement with other studies where cost effectiveness was regarded as an enabling factor towards the adoption of social media as a communication channel (Jones et al., 2015; Ainin et al., 2015; Ahmad et al., 2018; Basri \& Siam, 2019; Lepkowska-White et al., 2019; Ndiege, 2019; Qalati et al., 2020; Qalati et al., 2021). Speed, reach and cost effectiveness were also contributing factors in terms of the integration of social media as part of the marketing communication strategy (Valos et al., 2016).

\subsubsection{Reach}

The prevalence of social media means that social network platforms have made it possible to reach a much wider audience (Jones et al., 2015; Valos et al., 2016; Duffett et al., 2020; Kemp, 2020; Steel, 2021). Its general use by customers and businesses means that it is an accessible online ICT medium through which to communicate with current and potential customers. Facebook was highlighted as a platform with which the respondents were familiar, which facilitated its accessibility (Rootman, 2016; Crammond et al., 2018; Shaltoni et al., 2018). This sentiment was reflected by most of the respondents. Two respondents regarded the number of followers as an indication of the reach, with one stating that they had 11,000 followers, while the others estimated their number to be approximately 2,400 .

"Yes, the Facebook boosting does reach a bigger audience through the process I mentioned earlier...." [R2/6462:6872]

Sharing by followers and word of mouth on the social network platforms was regarded as important as this expanded their communication footprint to a much larger audience (Jones et al., 2015; Valos et al., 2016; Omenugha, 2018). The expanded reach potential for new markets and potential new clients is affirmed by Ahmad et al., 2018 and Bocconcelli et al., 2017. The former investigated the adoption of social media and its impact amongst small and medium businesses in the UAE whereas the latter found that struggling machinery suppliers were able to expand their market and grow sales due to social media activity. The independent food retailer respondents in the current study are almost exclusively community stores whose business footprint is limited to the community they serve. Hence, the possible reach extends their area of influence via social media. 


\subsubsection{Accessibility}

Accessibility was understood by the respondents as affording wide appeal and reach by the retailers and customers, not requiring extensive knowledge to engage with, and ease of maintenance. The majority emphasized accessibility from the customer and retailer perspective.

“Well I believe Facebook is the one most people use. So that one would have the most effect.” [R7/1044:1130]

The relative ease with which customers and retailers alike engage social media as a contact point suggest that this interactive ICT medium is accessible to users and therefore presents an opportunity to create contact points with customers and communities around stores (Kemp, 2020). A number of followers, claimed by two of the respondents, affirm the notion of accessibility. All the respondents in the current study were aware of social media, which suggests familiarity of this online ICT medium. Ndiege (2019) investigated social media usage for strategic positioning by small and medium businesses in a developing country and revealed that accessibility was a factor that motivated the respondents to use social media whereas the relative ease of setting up the online presence was an enabling factor that promoted the adoption of e-marketing in a study by Shaltoni et al. (2018) in a similar emerging market context. The assertion of the accessibility of social network sites lies in the ease with which both businesses and consumers engage and interact through this interactive ICT medium. The statements by the respondents of the current study support and confirm the accessibility sentiments of several other studies (Dahnil et al., 2014; Ainin et al., 2015; Ndiege, 2019; Kemp, 2020).

\subsubsection{Customer Relationships}

Engaging the customer community was important to the respondents. A few felt that feedback from the customer was important because it presented an opportunity to correct any negative instances whereas other respondents felt that social media enabled them to become part of the community. Similarly, some respondents considered the social network platforms as an interactive ICT medium through which they could build relationships with their customers. Customer-driven word of mouth promotion was regarded because of fostering good relationships with customers by some respondents.

"We have 2,400 followers and interruptions [posts and customer feedback], which are what I like. You want people who respond. You want people who get your material and you want people to respond to as it become a community rather being just a shop." [R3/1979:2283]

Connecting with and developing online customer relationships might be beneficial to the business, while is possible through social media (He et al., 2014; Ainin et al., 2015; Crammond et al., 2018; Omenugha, 2018; Ndiege, 2019; Chatterjee \& Kumar Kar, 2020). Joining social networks in the community they serve would also help raise their profile. This sentiment is reflected in the results of current literature and customer relationships was also confirmed by several other studies as a social media usage enabling factor (Jagongo \& Kinyua, 2013; Omenugha, 2018; Gabbianelli \& Pencarelli, 2021; Saleh, 2021; Siti-Nabiha et al., 2021). Additionally, Valos et al. (2016) noted the role and benefits of social media as a two-way communication channel that facilitated the growth of relationships. Twitter and Facebook were found to be the predominant social network platforms used by marketers to engage with customers in a study conducted by Vohra and Bhardwaj (2016) in India. The results of the current study are further supported by Ahmad et al. (2018) who found that social media usage resulted in improving brand awareness, grew sales and fostered customer relationships.

\subsection{Factors Inhibiting Social Media Usage as a Communication Channel}

Inhibiting factors are those that retard or block the use of social network platforms as a communication channel. The respondents revealed the circumstances under which adopting this channel would be difficult. The non-adopters cited personal and business reasons for their decision such as knowledge, time and circumstance, whereas those already using social media as a communication strategy described actual lived experiences that hamper its use. Figure 3 illustrates the factors retarding or preventing social media usage as a communication strategy by independent food retailer SMEs in South Africa. 
Figure 3. Factors Inhibiting Social Media Usage

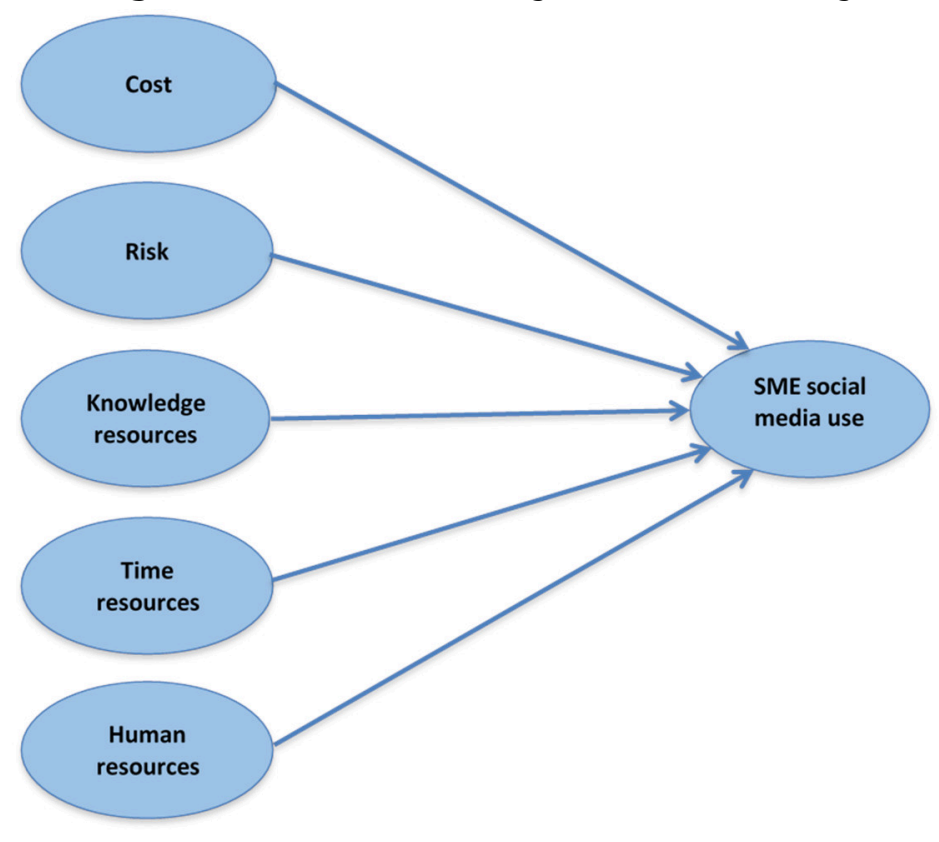

Source: Own elaboration

\subsubsection{Cost}

Cost was cited by several respondents as an inhibiting factor to adopting social media as a strategic communication channel, especially since boosting the Facebook posts in order to achieve the desired reach raised the cost of using this medium.

"The thing is that it has become more expensive and has become harder to reach the people you want to reach." [R2/6925:7401]

SMEs are generally regarded as lacking resources compared to larger enterprises that might have more capacity (Shaltoni et al., 2018). This suggests that businesses lacking in resources will look for the most cost effective way to promote themselves. Current literature points to social media as being a cost-effective method to communicate with customers (Ainin et al., 2015; Jones et al., 2015; He et al., 2017; Ahmad et al., 2018; Crammond et al., 2018; Ndiege, 2019; Ntshingila, 2020; Qalati et al., 2020; Qalati et al., 2021; Saleh, 2021), but other studies also indicated that social media was not cost effective (Dlodlo \& Dhurup, 2010; Oji et al., 2017; Chatterjee \& Kumar Kar, 2020; Kwon et al., 2021).

\subsubsection{Risk}

The risk of exposing themselves to negative comment and sentiment that might adversely affect their businesses because of their social media activity was expressed by the majority of the respondents. This consideration influenced the level of social media activity undertaken by the respondents. The findings suggest that negative feedback is part of social network platform feedback and the result was consequent of the manner in which the customer feedback was handled (Bae \& Zamrudi, 2018; Ndiege, 2019; Alzougool, 2019).

"What I find unfair about social platforms is that one cannot respond without getting a whole lot of mixed things coming in and sometimes it portrays your place unfairly." [R8/4449:5333]

\subsubsection{Resources}

Knowledge Resources. Although the respondents had indicated that they were aware of social media, the platforms that made it up and the opportunities that they presented, the lack of knowledge to take full advantage of this online ICT medium was acknowledged by some of the respondents. This included admitting that the function was delegated to knowledgeable family members when more information was required and coaching was needed. Dlodlo and Dhurup (2010) examined barriers to adopting e-marketing among small and medium businesses in the Vaal triangle (South Africa), which revealed that $29 \%$ of the respondents regarded emarketing as a threat. This assertion might be partly a result of lack of familiarity of this online ICT medium as conceded by $54 \%$ of the respondents. Jones et al. (2015); Taiminen and Karjaluoto (2015); Chatterjee and Kumar Kar (2020); and Salam et al. (2021) found that a lack of knowledge in using or maintaining a social network presence was an inhibitor of effective use. It is reasonable to assert that the level of knowledge with regard to social media and the meaningful application of the various social network platforms as a strategic communication channel can be considered a major finding in this study. The belief that social media is 
regarded as a threat (Dlodlo \& Dhurup, 2010; Oji et al., 2017) is supported by this study. This study found that some independent retailers exhibited an understanding of the platforms as evidenced by their activity, which included segmenting the messaging according to product type and audience demographics, whereas others lacked the necessary knowledge to extract optimal value by delegating the function to family members with the necessary skills. Although this finding might seem to contradict the accessibility of this medium as a communication channel, it is important to note that familiarity of the social network platform does not suggest the ability to extract full value from this channel as illustrated above and confirmed by He et al. (2017). This is notion is also consistent with findings of McCann and Barlow (2015); Ndiege (2019); and Olsson and Bernhard (2020).

Time Resources. Time as a resource was cited by several respondents as a factor inhibiting social media usage as a marketing communication platform. Most of the respondent retailers undertake tasks that might be performed by other people in bigger stores due to their operating structure, which therefore contributes to the reported lack of available time to engage social media.

"I think it is more time wise and having someone dedicated to doing that. I am not going to be able to do it if I am running around doing everything...." [R11/1687:2275]

Availability of time for online communication whilst having to multitask as an owner due to lack of people assigned to specific tasks is a consistent finding of the current study given the operational makeup of the independent retailer. Jones et al. (2015) also found that managers had difficulty in maintaining their platforms due to a lack of time. He et al. (2017) cited two examples of businesses discontinuing social media usage because of frustration with the maintenance task, which might have been partly caused by the time needed for the task. Ndiege (2019) investigated social media technology usage as strategic positioning by small and medium businesses in Kenya and found that the time needed to manage the online presence was a challenge for the respondents. Lepkowska-White et al. (2019) also disclosed that SME restaurants in the US did not have the time to adequately implement social media strategies effectively.

Human Resources. Similarly, to time as a constraint, available personnel with the capacity to undertake the function was seen as a problem by several respondents.

"I would have to get someone to handle that. I would have to employ someone for the social media platforms under my direction. It also means that the person has to be in the shop and have the knowledge of what is happening in order to respond to customer queries on the platforms." [R11/5809:6087]

Human resources are usually regarded as one of the resources that affect the functioning of businesses. In the current study, time and human resources are closely linked as tasks are usually carried out by the owner of the business. The exception to this was a respondent whose manager maintained the Facebook page and another respondent relied on family members, whereas the other respondents maintained their own profiles. The fact that the manager undertook the task of maintaining the online ICT medium points to a lack of capacity by the owner. Similarly, one of the retailers delegated the responsibility to family members as he lacked sufficient knowledge of the platform (Jones et al., 2015). The same can be said of other respondents with regard to a lack of knowledge to engage the social network platforms in a meaningful way, or having people in their business to do so on their behalf. A similar situation was found by Taiminen and Karjaluoto (2015) regarding uncertainty of how to use new digital tools or getting someone able to do so. In certain instances, this function was done infrequently due to lack of time (Lepkowska-White et al., 2019; Ndiege, 2019), the effort required (He et al., 2017), or the owner did not have the necessary skills to do so purposefully (McCann \& Barlow, 2015; Kwon et al., 2021; Salam et al., 2021).

\section{Conclusions and Implications}

This inquiry provided evidence that independent food retailer SMEs do engage social media as a communication channel. The level to which this online ICT medium has been adopted was influenced by personal, business and environmental factors that enabled, motivated or impeded its use. The results illustrate the predominance of Facebook as the social network platform of choice by the respondents and the varied use of other platforms such as Twitter, Instagram, Pinterest and WhatsApp, thereby reflecting the results of other studies (Ahmad et al., 2018; Ndiege, 2019; Saleh, 2021). The study revealed that social media was used by SMEs due to its PU and PEOU, which supported the TAM, but a number of other enabling and inhibiting factors were also affirmed to have an influence on independent food retailer SMEs in South Africa.

Cost effectiveness was found to be an important consideration for the respondent retailers who asserted that social media presented an inexpensive channel through which to communicate and interact with current and potential customers. This is consistent with findings of other studies, which confirmed the cost effectiveness of social media as a communication channel (He et al., 2017; Ahmad et al., 2018; Ndiege, 2019; Ntshingila, 2020; Qalati et al., 2020; Qalati et al., 2021; Saleh, 2021). It was also concluded that this interactive ICT medium made it possible to reach potential customers outside their traditional trading footprint than would be possible 
with traditional communication media (Bocconcelli et al., 2017; Ahmad et al., 2018; Ntshingila, 2020; Steel, 2021). Given that half of the world's population are active social media users (Kemp, 2020), familiarity with the different social network platforms made it easier for the respondent retailers to engage and interact with customers on these platforms (Shaltoni et al., 2018). This illustrates the possible benefits through the accessibility of social media in both the emerging and developed markets. The interactive nature of social media poses potential risks to businesses as they interact with customers and the manner in which they handle positive and negative feedback from customers (Harris \& Rae, 2009; Dahnil et al., 2014; Bae \& Zamrudi, 2018; Ndiege, 2019). This also provides an opportunity to generate a relationship with customers as a result of online interaction with them (He et al., 2014; Ainin et al., 2015; Chatterjee \& Kumar Kar, 2020; Gabbianelli \& Pencarelli, 2021). The respondents viewed the process of responding to emerging comments from customers as part of forging a relationship with them in the current study. Valos et al. (2016) noted the benefits of growing relationships with customers through the two-way online communication made possible by social media.

However, respondents reflected that there were considerations, which acted as barriers to social media usage. Reputational risk because of negative feedback broadcast by customers on social network platforms was a concern raised by retailers, as they had no control over the discourse put forward by consumers. Efforts to implement an effective online communication program were hampered by lack of resources such as an adequate knowledge of social network platforms in some cases, which limited the value that could be extracted from this online ICT medium. The availability of time to engage social network platforms was restricted in some cases given that these retailers had too many demands on their time due to insufficient human resources to cover all areas of the businesses.

Risk (Harris \& Rae, 2009; Ahamat et al., 2017; Alzougool, 2019, Ndiege, 2019) and available resources (Grimmer et al., 2017; Grimmer et al., 2018; Olsson \& Bernhard, 2020), which included knowledge (Jones et al., 2015; Chatterjee \& Kumar Kar, 2020; Kwon et al., 2021; Salam et al., 2021), time (Jones et al., 2015; He et al., 2017; Lepkowska-White et al., 2019), human capacity (Durkin et al., 2013; Jones et al., 2015; Olsson \& Bernhard, 2020) and costs (Dlodlo \& Dhurup, 2010; Oji et al., 2017; Chatterjee \& Kumar Kar, 2020; Kwon et al., 2021) were concluded as barriers to social media in other studies, which mirrored concerns identified in the current study.

Retailer-focused studies that are situated in the African developing country context are available, but mostly concentrate on issues relating to competitiveness (Badenhorst-Weiss \& Cilliers, 2019; Makhitha, 2016; Makhitha, 2017; Goko, 2017; Masojada, 2018; Lányi et al., 2021). The results of the current study serves to bridge this knowledge gap owing to the scope of research and specific focus on the independent food retailers and the food retail industry. Other studies in developed countries investigating social media use among SMEs that retailers as part of the sample include: He et al. (2017) found Facebook was the dominant platform of choice; Bae and Zamrudi (2018) revealed that generating customer relationships was a motivational factor; Taiminen and Karjaluoto (2015) found that the challenges of extracting full value from social network platforms was reflected by the results; Crammond et al. (2018) reflected environmental pressure as a motivational factor; and Durkin et al. (2013) revealed that SMEs were anxious to adopt social media, which was perceived as being an essential tool for business growth. Therefore, the study fulfils the need for additional research on SME social media usage in developing countries (Lepkowska-White et al., 2019; Gabbianelli \& Pencarelli, 2021; Kwon et al., 2021) and other countries (Alzougool, 2019; Qalati et al., 2021; Salam et al., 2021). Additionally, given the paucity of available literature focusing on social media marketing communication usage by SMEs, this study addresses a gap in the current knowledge dealing with this topic, which was mandated by Lepkowska-White et al. (2019); Rajahonka and Villman (2019); Olsson and Bernhard (2020); and Siti-Nabiha et al. (2021). Kwon et al. (2021) also assert that social media is an important marketing and communications tool for SMEs, but there is a lack of inquiry that examine factors that influence social media usage intentions, which was also addressed by this current inquiry.

From a theoretical perspective, this study confirmed that PU and PEOU of social network platforms were evident among SMEs and were likely to influence the adoption of social media - this notion was supported Chatterjee and Kumar Kar (2020); Salam et al. (2021); and Kwon et al. (2021) TAM-related research. However, this inquiry made new contributions to this theoretical framework via the examination of several external enabling factors that served to drive social media adoption by independent food retailer SMEs. Additionally, this research also identified some factors that inhibited social media usage as a communication channel, which were not considered by the original versions of the TAM. Therefore, this research added to the limited literature via the exploration of external factors influence on the use of social media as a communication channel. The inquiry also provides theoretical insight for further studies on the use of social media by independent food retailers or similar small businesses.

From a practical perspective, this research provides a greater understanding of the acceptance of new technology (i.e. social media usage) as a communication channel among food retailer SMEs in a developing country, which could promote future growth social media usage as means to find solutions for business-related issues. The identification of enabling and inhibiting technology acceptance factors can assist owners and 
managers to find new marketing communication strategies and tactics to promote their businesses. The independent food retailers observed that social media was useful in terms of cost effectiveness, accessibility, reach and customer relationship building, which might facilitate potentially lucrative marketing communication strategies for SMEs. Furthermore, the adoption of social media marketing communications on platforms such a Facebook has grown in importance since it positively influence SMEs performance both financially and non-financially (Salam et al., 2021), and represents as opportunity for SMEs that have not yet considered this digital ICT platform. Lastly, the research serves as a catalyst for policy makers, industry and SME developmental organizations to support and invest in SMEs in order to improve their digital capabilities in South Africa and other developing countries. Practical considerations include training, research, financial assistance, and the identification of organizations that can provide SMES with digital tools and opportunities, especially since many SMEs have limited resources and digital expertise.

\section{Limitations and Future Research Direction}

This exploratory study contained a sample size of only eleven independent retailers and the locality of the study (the Cape Town region) preclude the possibility of generalizability of the findings, as they are pertinent to the respondents of the study. The focus of the study was social media usage as a communication medium, which did not consider other channels (for example websites). Although platforms such as Twitter, Instagram and WhatsApp were noted as being used by the respondents, Facebook was established as the dominant social network platform of choice by the respondents, which suggests that the findings are slanted towards Facebook usage. Future studies can expand the concentration of the study to include additional platforms for more inclusive results, or can select specific platforms as the focus of study (Duffett et al., 2019). The recommendations suggested might not be applicable to other social network platforms not covered in this study. Nevertheless, these findings can form the basis for further research to explore the factors that influence independent food retailer SMEs use of social media as a marketing communication conduit to in order engage with customers and communities.

\section{Footnotes}

${ }^{1}$ The code indicates the participant number and characters of the quotation for a specific ATLAS.ti project. For example, "R9/3311:3356" indicates that the quotation comes from the ninth participant's transcript, and begins with character 3311 and ends with character 3356 in the specific transcript. 


\section{References}

Ahamat, A., Shahkat Ali, M. S., \& Hamid, N. (2017). Factors influencing the adoption of social media in small and medium enterprises (SMEs). IJASOS- International E-journal of Advances in Social Sciences, 3(8), 338-348. https://doi.org/10.18769/ijasos.336544

Ahmad, S. Z., Ahmad, N., \& Abu Bakar, A. R. (2018). Reflections of entrepreneurs of small and medium-sized enterprises concerning the adoption of social media and its impact on performance outcomes: Evidence from the UAE. Telematics and Informatics, 35(1), 6-17. https://doi.org/10.1016/j.tele.2017.09.006

Ainin, S., Parveen, F., Moghavvemi, S., Jaafar, N. I., \& Mohd Shuib, N. L. (2015). Factors influencing the use of social media by SMEs and its performance outcomes. Industrial Management \& Data Systems, 115(3), 570-588. https://doi.org/10.1108/IMDS-07-2014-0205

Al-Qaysi, N., Mohamad-Nordin, N., \& Al-Emran, M. (2020). A Systematic Review of Social Media Acceptance From the Perspective of Educational and Information Systems Theories and Models. Journal of Educational Computing Research, 57(8), 2085-2109. https://doi.org/10.1177/0735633118817879

Al-Qaysi, N., Mohamad-Nordin, N., \& Al-Emran, M. (2020). Employing the technology acceptance model in social media: A systematic review. Education and Information Technologies, 25(6), 4961-5002. https://doi.org/10.1007/s10639-020-10197-1

Alzougool, B. (2019). The use and continuance use of social media applications by small and medium enterprises in Kuwait. Global Knowledge, Memory and Communication, 68(6/7), 471-490. https://doi.org/10.1108/GKMC-11-2018-0094

Amoah, J., \& Jibril, A. B. (2021). Social Media as a Promotional Tool Towards SME's Development: Evidence from the Financial Industry in a Developing Economy. Cogent Business \& Management, 8(1), 1923357. https://doi.org/10.1080/23311975.2021.1923357

Appel, G., Grewal, L., Hadi, R., \& Stephen, A. T. (2020). The future of social media in marketing. Journal of the Academy of Marketing Science, 48(1), 79-95. https://doi.org/10.1007/s11747-019-00695-1

Badenhorst-Weiss, J. A., \& Cilliers, J. O. (2019). Competitive advantage of independent small businesses in Soweto. Southern African Business Review, 18(3), 1-21. https://doi.org/10.25159/1998-8125/5683

Bae, L. B., \& Zamrudi, M. F. Y. (2018). Challenge of social media marketing \& effective strategies to engage more customers: Selected retailer case study. International Journal of Business and Society, 19(3). http://www.ijbs.unimas.my/images/repository/pdf/Vol19-no3-paper18.pdf

Barnard, S. M., Bothma, C. H., \& Cant, M. C. (2017). The identification of criteria for the optimal use of Facebook pages for marketing purposes: A South African perspective. Journal of Business and Retail Management Research, 11(2). https://jbrmr.com/details\&cid=257

Basri, W. S. M., \& Siam, M. R. A. (2019). Social media and corporate communication antecedents of SME sustainability performance. Journal of Economic and Administrative Sciences, 35(3), 172-182. https://doi.org/10.1108/JEAS-01-2018-0011

Bocconcelli, R., Cioppi, M., \& Pagano, A. (2017). Social media as a resource in SMEs' sales process. Journal of Business \& Industrial Marketing, 32(5), 693-709. https://doi.org/10.1108/JBIM-11-2014-0244

Boonmalert, W., Ayasanond, C., \& Phoothong, B. (2021). A Causal Influence Model of Innovation and Digital Marketing on the Small and Medium Enterprise (SME) Performance in Thailand. European Journal of Molecular \& Clinical Medicine, 08(03), 63-72. https://ejmcm.com/article_8317.html

Boyce, C., \& Neale, P. (2006). Conducting In-Depth Interviews: A Guide for Designing and Conducting InDepth Interviews. Pathfinder International, 2(May)

Braojos-Gomez, J., Benitez-Amado, J., \& Javier Llorens-Montes, F. (2015). How do small firms learn to develop a social media competence? International Journal of Information Management, 35(4), 443-458. https://doi.org/10.1016/j.ijinfomgt.2015.04.003

Chatterjee, S., \& Kumar Kar, A. (2020). Why do small and medium enterprises use social media marketing and what is the impact: Empirical insights from India. International Journal of Information Management, 53. https://doi.org/10.1016/j.ijinfomgt.2020.102103

Chhonker, M. S., Verma, D., \& Kar, A. K. (2017). Review of Technology Adoption frameworks in Mobile Commerce. Procedia Computer Science, 122, 888-895. https://doi.org/10.1016/j.procs.2017.11.451

Crammond, R., Omeihe, K. O., Murray, A., \& Ledger, K. (2018). Managing knowledge through social media. Baltic Journal of Management, 13(3), 303-328. https://doi.org/10.1108/BJM-05-2017-0133

Creswell, J. W. (2013). Qualitative Inquiry and Research Design: Choosing among Five Approaches. Sage Publications

Curran, J., \& Blackburn, R. (2001). Researching the Small Business. Sage Publications

Dahnil, M. I., Marzuki, K. M., Langgat, J., \& Fabeil, N. F. (2014). Factors Influencing SMEs Adoption of Social Media Marketing. Procedia - Social and Behavioral Sciences, 148, 119-126.

https://doi.org/10.1016/j.sbspro.2014.07.025

Das Nair, R., \& Dube, S. C. (2015). Competition, Barriers to Entry and Inclusive Growth: Case Study on Fruit and Veg City. SSRN Electronic Journal. https://doi.org/10.2139/ssrn.2716049 
Das Nair, R., \& Dube, S. C. (2015). The Expansion of Regional Supermarket Chains: Changing Models of Retailing and the Implications for Local Supplier Capabilities in South Africa, Botswana, Zambia, and Zimbabwe. SSRN Electronic Journal. https://doi.org/10.2139/ssrn.2923047

Davis, F. D. (1989). Perceived Usefulness, Perceived Ease of Use, and User Acceptance of Information Technology. MIS Quarterly, 13(3), 319. https://doi.org/10.2307/249008

Davis, F. D., Bagozzi, R. P., \& Warshaw, P. R. (1989). User Acceptance of Computer Technology: A Comparison of Two Theoretical Models. Management Science, 35(8), 982-1003. https://doi.org/10.1287/mnsc.35.8.982

Dlodlo, N., \& Dhurup, M. (2010). Barriers to e-marketing adoption among small and medium enterprises (SMEs) in the Vaal Triangle. Acta Commercii, 10(1). https://doi.org/10.4102/ac.v10i1.126

DSBD (2019). Revised Schedule 1 of the National Definition of Small Enterprise in South Africa. Notice 399 of 2019

Duffett, R. (2020). South African Millennials' Attitudes towards the Communications Effect of YouTube Marketing. The African Journal of Information Systems, 13(1). https://digitalcommons.kennesaw.edu/ajis/vol13/iss1/2/

Duffett, R. (2020). The YouTube Marketing Communication Effect on Cognitive, Affective and Behavioural Attitudes among Generation Z Consumers. Sustainability, 12(12), 5075. https://doi.org/10.3390/su12125075

Duffett, R. G., Edu, T., \& Negricea, I. C. (2019). YouTube marketing communication demographic and usage variables influence on Gen Y's cognitive attitudes in South Africa and Romania. The Electronic Journal of Information Systems in Developing Countries, 85(5). https://doi.org/10.1002/isd2.12094

Duffett, R. G., Edu, T., Negricea, I. C., \& Zaharia, R. M. (2020). Modelling the effect of youtube as an advertising medium on converting intention-to-purchase into purchase. Transformations in Business and Economics, 19(1)

Durkin, M., McGowan, P., \& McKeown, N. (2013). Exploring social media adoption in small to medium-sized enterprises in Ireland. Journal of Small Business and Enterprise Development, 20(4), 716-734. https://doi.org/10.1108/JSBED-08-2012-0094

Dwivedi, Y. K., Rana, N. P., Chen, H., \& Williams, M. D. (2011). A Meta-analysis of the Unified Theory of Acceptance and Use of Technology (UTAUT). Paper presented at IFIP Advances in Information and Communication Technology. https://doi.org/10.1007/978-3-642-24148-2_10

Fan, M., Qalati, S. A., Khan, M. A. S., Shah, S. M. M., Ramzan, M., \& Khan, R. S. (2021). Effects of entrepreneurial orientation on social media adoption and SME performance: The moderating role of innovation capabilities. PLOS ONE, 16(4), e0247320. https://doi.org/10.1371/journal.pone.0247320

Gabbianelli, L., \& Pencarelli, T. (2021). Exploring some marketing practices in management consulting firms: evidence from small service firms in Italy. The TQM Journal, ahead-of-p(ahead-of-print). https://doi.org/10.1108/TQM-12-2019-0308

Gbadeyan, R. A., \& Mensah, F. P. B. (2016). Social Media Marketing Strategies for Small Business Sustainability: a Study on Selected Online Shoppers in Cape Coast, Ghana. FUTA Journal of Management and Technology, 1(1)

Geller, L., \& Ntloedibe, M. (2019). South Africa retail foods industry. Global Agricultural Information Network (GAIN)

Goko, C. (2017). Spaza shops growing strongly, study shows. https://www.businesslive.co.za/bd/business-andeconomy/2017-06-26-spaza-shops-growing-strongly-study-shows/

Goldstuck, A., \& Du Plessis, T. (2016). SA social media landscape 2017. http://www.worldwideworx.com/wpcontent/uploads/2016/09/Social-Media-2017-Executive-Summary.pdf

Grewal, D., Roggeveen, A. L., \& Nordfält, J. (2017). The Future of Retailing. Journal of Retailing, 93(1), 1-6. https://doi.org/10.1016/j.jretai.2016.12.008

Grimmer, L., Grimmer, M., \& Mortimer, G. (2018). The more things change the more they stay the same: A replicated study of small retail firm resources. Journal of Retailing and Consumer Services, 44, 54-63. https://doi.org/10.1016/j.jretconser.2018.05.012

Grimmer, L., Miles, M. P., Byrom, J., \& Grimmer, M. (2017). The Impact of Resources and Strategic Orientation on Small Retail Firm Performance. Journal of Small Business Management, 55, 7-26. https://doi.org/10.1111/jsbm.12368

Gujral, M., Rauzela, M., \& Chuchu, T. (2016). An Application of the Marketing Mix and Online Marketing as a Business Strategy for SMME Cafes in South Africa. Journal of Economics and Behavioral Studies, 8(3(J)), 14-25. https://doi.org/10.22610/jebs.v8i3(J).1285

Hair, J. F., Celsi, M. W., Ortinau, D. J., \& Bush, R. P. (2017). Essentials of Marketing Research (4th ed). McGraw-Hill Education

Harris, L., \& Rae, A. (2009). Social networks: the future of marketing for small business. Journal of Business Strategy, 30(5), 24-31. https://doi.org/10.1108/02756660910987581 
He, W., Wang, F., Chen, Y., \& Zha, S. (2017). An exploratory investigation of social media adoption by small businesses. Information Technology and Management, 18(2), 149-160. https://doi.org/10.1007/s10799-015-0243-3

He, W., Wang, F., \& Zha, S. (2014). Enhancing social media competitiveness of small businesses: insights from small pizzerias. New Review of Hypermedia and Multimedia, 20(3), 225-250. https://doi.org/10.1080/13614568.2014.889225

Itliong, J. (2020). Online strategies for small businesses affected by Covid-19: a social media and social commerce approach. (Doctoral dissertation).. California State University, San Bernardino, US. https://scholarworks.lib.csusb.edu/etd/1160/

Jagongo, A., \& Kinyua, C. (2013). The Social Media and Entrepreneurship Growth. International Journal of Humanities and Social Science, 3(10). http://www.ijhssnet.com/journal/index/1846

Jones, N., Borgman, R., \& Ulusoy, E. (2015). Impact of social media on small businesses. Journal of Small Business and Enterprise Development, 22(4), 611-632. https://doi.org/10.1108/JSBED-09-2013-0133

Jordan, R. S. (2018). Social Media Marketing Strategies Used by Small Retail Businesses. (Doctoral dissertation).. Walden University, Minneapolis. https://scholarworks.waldenu.edu/dissertations/5883/

Kelso, A. (2018). Independent grocery growth reflects demand for specialty and organic fare. https://www.fooddive.com/news/independent-grocery-growth-reflects-demand-for-specialty-and-organicfare/530978/

Kemp, S. (2020). Digital in 2020. https://wearesocial.com/digital-2020

Kemp, S. (2018). Digital in 2018: World's internet users pass the 4 billion mark. https://wearesocial.com/blog/2018/01/global-digital-report-2018

Kongolo, M. (2010). Job creation versus job shedding and the role of SMEs in economic development. African Journal of Business Management, 4(11), 2288-2295. https://academicjournals.org/journal/AJBM/articleabstract/10B0E3226503

Kumwenda-Mtambo, O., \& Strydom, T. J. (2017). After 159 years, Stuttafords shuts up shop. https://www.moneyweb.co.za/news/companies-and-deals/after-159-years-stuttafords-shuts-up-shop/

Kwon, W., Woo, H., Sadachar, A., \& Huang, X. (2021). External pressure or internal culture? An innovation diffusion theory account of small retail businesses' social media use. Journal of Retailing and Consumer Services, 62, 102616. https://doi.org/10.1016/j.jretconser.2021.102616

Lányi, B., Hornyák, M., \& Kruzslicz, F. (2021). The effect of online activity on SMEs' competitiveness. Competitiveness Review: An International Business Journal, 31(3), 477-496. https://doi.org/10.1108/CR-01-2020-0022

Lepkowska-White, E., Parsons, A., \& Berg, W. (2019). Social media marketing management: an application to small restaurants in the US. International Journal of Culture, Tourism and Hospitality Research, 13(3), 321-345. https://doi.org/10.1108/IJCTHR-06-2019-0103

Levy, M., \& Weitz, B. A. (2012). Retailing Management (8th ed.). McGraw-Hill/Irwin

Ligthelm, A. A. (2008). A targeted approach to informal business development: the entrepreneurial route. Development Southern Africa, 25(4), 367-382. https://doi.org/10.1080/03768350802316138

Liu, Z., Ben, S., \& Zhang, R. (2019). Factors affecting consumers' mobile payment behavior: a meta-analysis. Electronic Commerce Research, 19(3), 575-601. https://doi.org/10.1007/s10660-019-09349-4

Makhitha, K. M. (2017). Independent retailers in South Africa: how do they select their suppliers for survival? Journal of Contemporary Management, 14(1). https://journals.co.za/doi/10.10520/EJC-82d2bd554

Makhitha, K. M. (2017). Supplier selection criteria used by independent retailers in Johannesburg, South Africa. Journal of Business and Retail Management Research, 11(3), 72-84. https://doi.org/10.24052/JBRMR/274

Makhitha, K. M. (2016). Challenges impacting on small independent retailers performance in Soweto, Johannesburg in South Africa. Investment Management and Financial Innovations, 13(3), 258-266. https://doi.org/10.21511/imfi.13(3-1).2016.12

Malgas, B., Khatle, T., \& Mason, R. B. (2018). Job creation in the South African retail sector. Retail and Marketing Review, 13(1), 1-13. https://journals.co.za/doi/abs/10.10520/EJC-8135da9ec

MarketLine (2015). Food retail in South Africa. https://store.marketline.com/report/ohme3289--food-retail-insouth-africa/

Marshall, M. N. (1996). Sampling for qualitative research. Family Practice, 13(6), 522-526. https://doi.org/10.1093/fampra/13.6.522

Masojada, M. (2018). \#BizTrends2018: What is shaping grocery retail in South Africa - Part 1. https://www.bizcommunity.com/Article/196/731/172117.html

Massmart (2020). Integrated Annual Report for the year ended December 2019. https://www.massmart.co.za/iar2019/wp-content/uploads/Massmart_IAR_2019-1.pdf

Matarazzo, M., Penco, L., Profumo, G., \& Quaglia, R. (2021). Digital transformation and customer value creation in Made in Italy SMEs: A dynamic capabilities perspective. Journal of Business Research, 123, 642-656. https://doi.org/10.1016/j.jbusres.2020.10.033 
McCann, M., \& Barlow, A. (2015). Use and measurement of social media for SMEs. Journal of Small Business and Enterprise Development, 22(2), 273-287. https://doi.org/10.1108/JSBED-08-2012-0096

Michaelidou, N., Siamagka, N. T., \& Christodoulides, G. (2011). Usage, barriers and measurement of social media marketing: An exploratory investigation of small and medium B2B brands. Industrial Marketing Management, 40(7), 1153-1159. https://doi.org/10.1016/j.indmarman.2011.09.009

Ndiege, J. R. A. (2019). Social media technology for the strategic positioning of small and medium-sized enterprises: Empirical evidence from Kenya. The Electronic Journal of Information Systems in Developing Countries, 85(2), e12069. https://doi.org/10.1002/isd2.12069

Ngubelanga, A., \& Duffett, R. (2021). Modeling Mobile Commerce Applications' Antecedents of Customer Satisfaction among Millennials: An Extended TAM Perspective. Sustainability, 13(11), 5973. https://doi.org/10.3390/su13115973

Njie, B., \& Asimiran, S. (2014). Case Study as a Choice in Qualitative Methodology. IOSR Journal of Research \& Method in Education (IOSRJRME), 4(3), 35-40. https://doi.org/10.9790/7388-04313540

Ntshingila, N. (2020). Facebook publishes the global state of small business report. https://www.bizcommunity.com/Article/196/19/206400.html\#more

Odoom, R., Anning-Dorson, T., \& Acheampong, G. (2017). Antecedents of social media usage and performance benefits in small- and medium-sized enterprises (SMEs). Journal of Enterprise Information Management, 30(3), 383-399. https://doi.org/10.1108/JEIM-04-2016-0088

Oji, O. N. E., Iwu, C. G., \& Tengeh, R. K. (2017). Social media adoption challenges of small businesses: The case of restaurants in the Cape Metropole, South Africa. African Journal of Hospitality, Tourism and Leisure, 6(4). http://www.ajhtl.com/uploads/7/1/6/3/7163688/article_19_vol_6_4_2017.pdf

OK Foods (2021). Home: OK Franchise. https://www.okfd.com/franchisesales/home/

Olanrewaju, A. T., Hossain, M. A., Whiteside, N., \& Mercieca, P. (2020). Social media and entrepreneurship research: A literature review. International Journal of Information Management, 50, 90-110. https://doi.org/10.1016/j.ijinfomgt.2019.05.011

Olsson, A. K., \& Bernhard, I. (2020). Keeping up the pace of digitalization in small businesses-Women entrepreneurs' knowledge and use of social media. International Journal of Entrepreneurial Behavior \& Research, 27(2), 378-396. https://doi.org/10.1108/IJEBR-10-2019-0615

Omenugha, N. O. (2018). The Assimilation of Social Media in Marketing Management: A Case Review of Taliah's Strategy. Business and Management Studies, 4(3), 58. https://doi.org/10.11114/bms.v4i3.3573

Pick n Pay (2020). Integrated Annual Report, 2020. https://www.picknpayinvestor.co.za/downloads/annualreport/2020/pick-n-pay-iar.pdf

Qalati, S. A., Li, W., Ahmed, N., Ali Mirani, M., \& Khan, A. (2020). Examining the Factors Affecting SME Performance: The Mediating Role of Social Media Adoption. Sustainability, 13(1), 75. https://doi.org/10.3390/su13010075

Qalati, S. A., Yuan, L. W., Khan, M. A. S., \& Anwar, F. (2021). A mediated model on the adoption of social media and SMEs' performance in developing countries. Technology in Society, 64, 101513. https://doi.org/10.1016/j.techsoc.2020.101513

Rajahonka, M., \& Villman, K. (2019). Women Managers and Entrepreneurs and Digitalization: On the Verge of a New Era or a Nervous Breakdown? Technology Innovation Management Review, 9(6), 14-24. https://doi.org/10.22215/timreview/1246

Ramanathan, U., Subramanian, N., \& Parrott, G. (2017). Role of social media in retail network operations and marketing to enhance customer satisfaction. International Journal of Operations \& Production Management, 37(1), 105-123. https://doi.org/10.1108/IJOPM-03-2015-0153

Rootman, C. $(2016,03)$. How social medial tools influence brand image and buying behavior in the South African food retail. Paper presented at Proceedings of the 3rd Business \& Management Conference. https://doi.org/10.20472/BMC.2016.003.018

Salam, M. T., Imtiaz, H., \& Burhan, M. (2021). The perceptions of SME retailers towards the usage of social media marketing amid COVID-19 crisis. Journal of Entrepreneurship in Emerging Economies, ahead-of-p(ahead-of-print). https://doi.org/10.1108/JEEE-07-2020-0274

Saleh, Y. (2021). ICT, social media and COVID-19: evidence from informal home-based business community in Kuwait City. Journal of Enterprising Communities: People and Places in the Global Economy, 15(3), 395-413. https://doi.org/10.1108/JEC-07-2020-0131

Sarstedt, M., \& Mooi, E. (2014). A Concise Guide to Market Research: The Purpose, Data, and Methods using IBM SPSS Statistics (2nd ed.). Springer

Schmidt, H. J., B. Mason, R., Bruwer, J., \& Aspeling, J. (2017). Access to finance problems for small retail businesses in South Africa: comparative views from finance seekers (retailers) and finance providers (banks). Banks and Bank Systems, 12(2), 20-30. https://doi.org/10.21511/bbs.12(2).2017.02

Seidler, J. (1974). On Using Informants: A Technique for Collecting Quantitative Data and Controlling Measurement Error in Organization Analysis. American Sociological Review, 39(6), 816. https://doi.org/10.2307/2094155 
Shaltoni, A. M., West, D., Alnawas, I., \& Shatnawi, T. (2018). Electronic marketing orientation in the Small and Medium-sized Enterprises context. European Business Review, 30(3), 272-284.

https://doi.org/10.1108/EBR-02-2017-0034

Shoprite Holdings (2020). Integrated annual report 2020.

https://www.shopriteholdings.co.za/content/dam/MediaPortal/documents/shoprite-holdings/integratedreport/2020/shoprite_ir_2020_ia.pdf

Siti-Nabiha, A. K., Nordin, N., \& Poh, B. K. (2021). Social media usage in business decision-making: the case of Malaysian small hospitality organisations. Asia-Pacific Journal of Business Administration, 13(2),

272-289. https://doi.org/10.1108/APJBA-08-2020-0276

Spar (2021). Spar homepage. https://www.spar.co.za/Home

Srichookiat, S., \& Jindabot, T. (2017). Small family grocers' inherent advantages over chain stores: a review. International Journal of Retail \& Distribution Management, 45(4), 446-462. https://doi.org/10.1108/IJRDM-04-2016-0050

Statista (2021). Retail trade sales in South Africa from 2013 to 2020. https://www.statista.com/statistics/233153/total-of-retail-net-sales-in-south-africa/

Steel, G. (2021). Going global - going digital. Diaspora networks and female online entrepreneurship in Khartoum, Sudan. Geoforum, 120, 22-29. https://doi.org/10.1016/j.geoforum.2021.01.003

Sutomo, E., Abdul Rahman, N. S., \& Romli, A. (2020). Determination of the influence factors on social commerce in SME: A review. International Journal of Software Engineering and Computer Systems, 6(2), 74-83. https://doi.org/10.15282/ijsecs.6.2.2020.4.0072

Taiminen, H. M., \& Karjaluoto, H. (2015). The usage of digital marketing channels in SMEs. Journal of Small Business and Enterprise Development, 22(4), 633-651. https://doi.org/10.1108/JSBED-05-2013-0073

Taylor, C., \& Gibbs, G. (2010). What is Qualitative Data Analysis (QDA)?

Thomas, L. (2018). Sears' 'tragic' bankruptcy turns to opportunity as US mall owners court Nobu hotels, Life Time Fitness to fill empty stores. https://www.cnbc.com/2018/10/27/sears-tragic-bankruptcy-turns-toopportunity-for-us-mall-owners.html

Tongco, M. D. C. (2007). Purposive Sampling as a Tool for Informant Selection. Ethnobotany Research and Applications, 5, 147. https://doi.org/10.17348/era.5.0.147-158

Torres de Oliveira, R., Indulska, M., Steen, J., \& Verreynne, M. (2020). Towards a framework for innovation in retailing through social media. Journal of Retailing and Consumer Services, 54. https://doi.org/10.1016/j.jretconser.2019.01.017

Tumsifu, E., \& Gekombe, C. (2020). Small and Medium Enterprises and Social Media Usage: A Fashion Industry Perspective. University of Dar es Salaam Library Journal, 15(1). https://www.ajol.info/index.php/udslj/article/view/210526

Tuten, T., \& Perotti, V. (2019). Lies, brands and social media. Qualitative Market Research: An International Journal, 22(1), 5-13. https://doi.org/10.1108/QMR-02-2017-0063

Valos, M. J., Haji Habibi, F., Casidy, R., Driesener, C. B., \& Maplestone, V. L. (2016). Exploring the integration of social media within integrated marketing communication frameworks. Marketing Intelligence \& Planning, 34(1), 19-40. https://doi.org/10.1108/MIP-09-2014-0169

Venkatesh, V., \& Bala, H. (2008). Technology Acceptance Model 3 and a Research Agenda on Interventions. Decision Sciences, 39(2), 273-315. https://doi.org/10.1111/j.1540-5915.2008.00192.x

Venkatesh, V., \& Davis, F. D. (2000). A Theoretical Extension of the Technology Acceptance Model: Four Longitudinal Field Studies. Management Science, 46(2), 186-204. https://doi.org/10.1287/mnsc.46.2.186.11926

Vohra, A., \& Bhardwaj, N. (2016). A Conceptual Presentation of Customer Engagement in the context of Social Media - An Emerging Market Perspective. International Journal in Management and Social Science, 4(1), 351-366

von Briel, F. (2018). The future of omnichannel retail: A four-stage Delphi study. Technological Forecasting and Social Change, 132, 217-229. https://doi.org/10.1016/j.techfore.2018.02.004

Wells, J. (2018). IGA's CEO is bringing independents into the new age. https://www.grocerydive.com/news/igas-ceo-is-bringing-independents-into-the-new-age/539888/

Wiid, J., \& Diggines, C. (2013). Marketing Research (2nd ed.). Juta

Wilson, A. (2006). Marketing Research: An Integrated Approach (2nd ed.). Pearson Education Limited

Winchester, J. (2017). Can the independent food retailer survive?. https://www.insight6.com/blog/canindependent-food-retailers-survive/

Wirtz, B. W., \& Göttel, V. (2016). Technology acceptance in social media: Review, synthesis and directions for future empirical research. Journal of Electronic Commerce Research, 17(2).

http://www.jecr.org/node/489

Woolworths (2020). Woolworths online shopping. http://www.woolworths.co.za/

Zikmund, W. G., \& Babin, B. J. (2013). Essentials of Marketing Research (5th ed.). Cengage Learnig 